\title{
PREDIKSI DAYA TAMPUNG KAPASITAS RUANG KELAS PADA PERGURUAN TINGGI SEBAGAI BAGIAN DARI TARGET PROMOSI PENERIMAAN MAHASISWA BARU: STUDI KASUS
}

\author{
Rorim Panday ${ }^{{ }^{*}}$ \\ ${ }^{1}$ Fakultas Ekonomi, Universitas Bhayangkara Jaya \\ *Email Korespondensi: indripan@gmail.com
}

\begin{abstract}
ABSTRAK
Universitas Bhayangkara Jaya adalah salah satu perguruan tinggi swasta di wilayah kopertis 3 dengan akreditasi institusi B. Pada semester genap 2016/2017 jumlah student bodynya mencapai 6443 mahasiswa, yang terdiri dari lima Fakultas dan satu Pasca Sarjana, yang dalam operasional kegiatan belajar mengajar menggunakan 73 ruang kelas, yang mana kapasitas ruangan rata-rata adalah 35 mahasiswa per kelasnya. Dengan kondisi tersebut, dan melihat trend minat calon mahasiswa masuk ke universitas Bhayangkara Jaya yang terus meningkat dari tahun ke tahun, menjadi permasalahan apakah dengan kondisi demikian masih dapat menerima mahasiswa baru untuk tahun ajaran 2017/2018, dan apakah kapasitas yang ada sudah optimum? Untuk itu dilakukan penelitian dengan menggunakan data sekunder yang terkait dengan penggunaan ruang kelas. Dengan menggunakan cara pendekatan empirik, yaitu menganalisa kapasitas ruang yang tersedia dan kapasitas ruang yang terpakai, maka dapat ditentukan berapa perkiraan sisa ruang yang masih ada dan berapa perkiraan jumlah mahasiswa yang dapat diterima pada periode tahun ajar 2017/2018. Jumlah ini sebagai prediksi target tim pemasaran universitas untuk merekrut calon mahasiswa baru. Implikasi manjerial dari hasil analisa ini, disampaikan dalam makalah ini.
\end{abstract}

Kata Kunci: Kapasitas ruang tersedia, kapasitas ruang terpakai, optimasi, prediksi.

\section{PENDAHULUAN}

Umumnya perguruan tinggi swasta di Indonesia, dalam pembiayaan operasional kegiatan belajar mengajar masih mengandalkan uang pendidikan yang diambil dari mahasiswa dan calon mahasiswa. Jumlah mahasiswa yang dapat dikelola akan sangat tergantung dari ruang kelas dan fasilitas yang dapat disediakan oleh perguruan tinggi tersebut, jumlah matakuliah yang ditawarkan pada setiap semester, jumlah kelas paralel untuk setiap matakuliah, kapasitas ruang kuliah, frekuensi penggunaan ruang kuliah dalam satu hari dan berapa hari perkuliahan dilaksanakan dalam satu minggu. Jumlah mahasiswa yang dapat dikelolan tersebut pada akhirnya akan menentukan jumlah dosen yang diperlukan untuk melaksanakan proses belajar mengajar. Sebagaimana yang telah ditetapkan oleh Dikti dalam Standar Nasional Pendidikan.(2005), jumlah mahasiswa untuk program studi Ilmu eksata adalah 20 sampai dengan 30 mahasiswa per kelasnya, sedangkan untuk program studi Ilmu sosial jumlah mahasiswanya adalah 30 sampai dengan 45 mahsiswa per kelasnya.

Universitas Bhayangkara Jaya (UBJ) adalah salah satu perguruan tinggi swasta di wilayah kopertis 3 dengan akreditasi institusi B. Pada semester genap 2016/2017 jumlah student bodynya mencapai 6443 mahasiswa, yang terdiri dari lima Fakultas dan satu Pasca Sarjana yang terdiri dari 
12 program studi yaitu 5 prodi teknik (IPA) dan 7 prodi ilmu sosial, yang dalam operasional kegiatan belajar mengajar menggunakan 73 ruang kelas, yang mana kapasitas ruangan rata-rata adalah 35 mahasiswa per kelasnya. Permasalahan yang dihadapi, apakah 73 ruang kelas tersebut sudah full capacity? Apakah masih dapat menampung mahasiswa baru untuk semester ganjil 2017/2018? Kalau memang masih bisa menampung mahasiswa baru, berapa banyak jumlah perkiraan yang dapat diterima. Jumlah calon mahasiswa yang dapat diterima, ini merupakan target dari tim pemasaran/promosi perguruan tinggi.

Berdasarkan data yang dicatat di universitas Bhayangkara Jaya, penerimaan mahasiswa baru dari tahun 2013 sampai dengan tahun 2016 terus meningkat, di gambarkan dalam grafik 1.

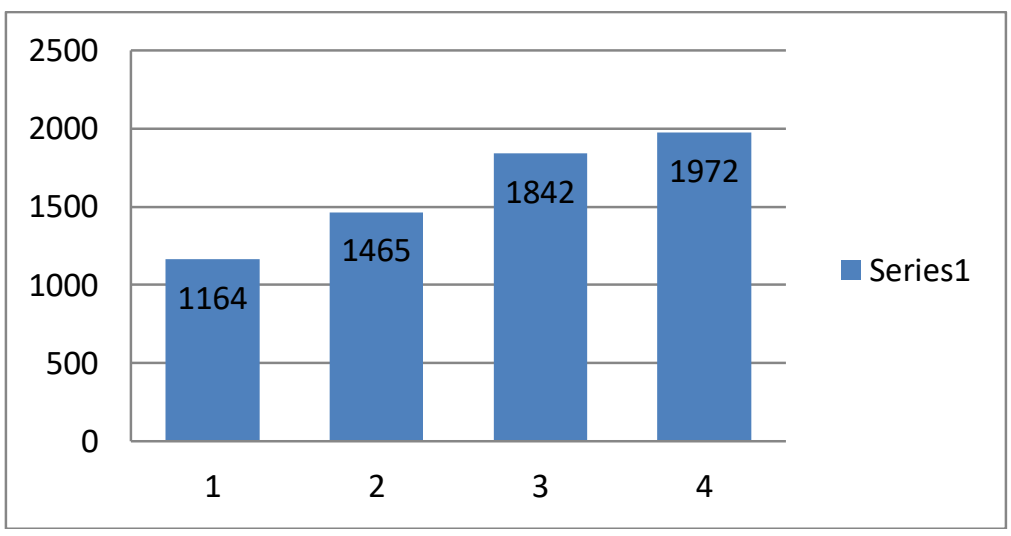

Grafik 1. Data trend penerimaan mahasiswa baru Sumber : Laporan feeder 2016/1

Dengan melihat pada kenyataan tersebut, diperkirakan jumlah calon mahasiswa yang dapat diterima di tahun 2017 diperkirakan akan meningkat. Tentunya peningkatan jumlah calon mahasiswa yang dapat diterima harus sesuai dan dapat ditampung dengan sisa jumlah ruang kelas yang ada.

Penelitian ini bertujuan untuk menjawab permasalahan tersebut dan apa implikasi manajerial yang mesti dilaksanakan untuk itu.

\section{LANDASAN TEORI}

Beberapa peneliti/ penulis menggunakan teori utilisasi, kapasitas dan okupansi untuk pengukuran penggunaan ruangan. Kapasitas ruangan perlu ditetapkan dalam perencanaan ruangan bangunan, karena memberi dampak yang besar pada biaya tetap, terutama ruangan bangunan yang memberikan nilai ekonomis. Dengan melakukan perencanaan kapasitas ruangan juga menentukan apakah permintaan akan ruangan dapat dipenuhi, atau apakah ruang yang ada akan berlebihan. (Martinich, 1997).

Jika kapasitas terlalu besar, kemungkinan sebagian kapasitas akan menganggur (idle) dan akan menimbulkan biaya tambahan yang dibebankan pada operasional atau dibebankan kepada pelanggan. Sebaliknya jika kapasitas terlalu kecil, keinginan pelanggan tidak dapat dilayani dan bahkan sebagian peluang bisnis akan hilang. Dalam hal perguruan tinggi, yang dimaksud dengan pelanggan adalah mahasiswa dan calon mahasiswa. 
Oleh karena itu penetapan ukuran kapasitas ruang, dengan tujuan pencapaian tingkat utilisasi tinggi dan tingkat pengembalian investasi yang tinggi, serta ukuran efisiensi sangat menentukan. Dengan perencanaan kapasitas yang akurat sebuah perguruan tinggi akan dapat mengetahui jumlah permintaan/ kebutuhan yang dapat dilayani dengan standar kualitas yang telah ditentukan. Perencanaan kapasitas harus dipandang dari tiga perspektif (Heizer 2008: 167), yaitu (1) kapasitas design, keluaran maksimum pada kondisi ideal, (2) kapasitas efektif, keluaran maksimum pada tingkat keluaran maksimum operasi tertentu dan (3) kapasitas aktual, keluaran nyata yang dapat dihasilkan oleh sebuah fasilitas. Kondisi yang baik adalah kapasitas aktual sama dengan kapasitas efektif.

Hal lain yang terkait dengan penggunaan ruangan adalah utilisasi ruangan. Utilisasi ruangan adalah untuk mengukur apakah dan bagaimanakah ruangan digunakan.Tingkat utilisasi adalah fungsi dari tingkat frekuensi dan tingkat okupansi.

Tingkat frekuensi adalah mengukur perbandingan antara waktu penggunaan ruangan dengan waktu penggunaan ruang yang tersedia, atau berapa kali penggunaan suatu ruangan dalam jangka waktu tertentu. Sedangkan tingkat okupansi adalah mengukur seberapa penuh ruangan dibandingkan dengan kapasitasnya yang telah ditentukan. Tingkat utilisasi dapat dinyatakan dalam bentuk aktual penggunaan berbanding dengan prediksi penggunaan.

Pada UK Higher Education. (2006), utilisasi ruangan didefinisikan untuk mengukur bagaimana ruangan digunakan, baik dalam bentuk seberapa sering ruangan digunakan dan, kapan mereka menggunakan, berapa banyak orang didalamnya. Dalam UK Higher Education. (2006), the National Audit Office's (NAO) Space Management in Higher Education (2006) : A Good Practice Guide (1996) menentukan perhitungan standar utilisasi ruangan sebagai berikut:

Space Utilisasion $=(\%$ frequency $\mathrm{x} \%$ occupancy $) / 100$

Dimana:

- $\%$ frekuensi adalah proporsi banyaknya jam pemakaian ruangan terhadap total jam yang tersedia per minggu

- \% okupansi adalah proporsi ukuran rata-rata kelompok terhadap kapasitas total untuk jam pemakaian ruangan.

Penelitian tentang penggunaan ruangan dilakukan oleh Panday, Rorim (2015), telah menggunakan rumus Space Utilisasion pada penelitiannya yang merupakan studi kasus pada gedung Fakultas Teknik universitas Pakuan, Bogor. Data yang digunakan adalah data sekunder yang berkaitan dengan jumlah mahasiswa yang mengambil matakuliah dan data penggunaan ruangan untuk perkuliahan. Dari data tersebut diketahui nilai okupansi dan nilai frekuensi pemakaian ruangan. Hasil penelitian ini menunjukkan bahwa Space utility dari penggunaan gedung fakultas teknik universitas Pakuan rata-rata adalah sebesar 14,19\%.

Selain itu peneliti Hesti (2010), melakukan optimalisasi kapasitas ruangan, mengkaitkan kapasitas minimum yang dicari menggunakan prinsip Break even point dan linier programmimg, dengan menggunakan beberapa asumsi. Untuk Pengukuran Utilitas, didefinisikan sebagai persentase kapasitas desain yang sesungguhnya telah dicapai. Sedangkan Utilisasi = Output aktual: Kapasitas desain. Untuk pengukuran efisiensi (Heizer, 2008: 158), Efisiensi adalah persentase kapasitas efektif yang sesungguhnya telah dicapai. Manajer operasi cenderung dievaluasi pada tingkat efisiensinya. Sehingga, Efisiensi = output aktual: kapasitas efektif. Untuk menentukan output aktual maka: Output aktual= kapasitas efektif $\times$ efisiensi. Rumus yang digunakan Hesti 
sedikit berbeda dengan UK Higher Education. Panday dan Hesti melakukan penelitian yang berkaitan dengan efisiensi penggunaan ruang kuliah.

Dalam penelitian ini, peneliti menggunakan sebagian rumus dan teori dari UK Higher Education, hanya saja dalam penelitian ini tidak diperlukan menghitung space utilization. Yang diperlukan adalah kapasitas rata-rata ruangan dan frekuensi penggunaan ruangan dalam satu hari dan dalam satu minggu, untuk menghitung banyaknya ruang kuliah/ sesi yang tersedia. Data banyaknya mata kuliah yang diambil oleh setiap mahasiswa, menunjukkan banyaknya kelas/ sesi yang berlangsung. Dengan menggunakan cara pendekatan empirik, yaitu menganalisa kapasitas ruang yang tersedia dan kapasitas ruang yang terpakai, maka dapat ditentukan berapa perkiraan sisa ruang kuliah/sesi yang masih ada dan berapa perkiraan jumlah mahasiswa yang dapat diterima pada periode tahun ajar 2017/2018.

\section{METODOLOGI PENELITIAN}

Penelitian ini menggunakan data primer dan data sekunder. Data primer diambil dengan cara melakukan riset langsung ke lapangan, dalam hal ini menghitung jumlah ruang fisik kuliah dari setiap fakultas dan prodi. Dari data primer tersebut dapat dilakukan hitungan pendekatan berapa ruang kuliah/sesi yang tersedia. Data sekunder diambil dari data roster setiap prodi, dimana dari roster tersebut dapat dihitung berapa banyak mata kuliah/sesi yang dilaksanakan, waktu pelaksanaan kuliah dan ruangan yang dipakai. Dari data sekunder dapat dihitung berapa banyak ruang kuliah/sesi yang terpakai. Selisih antara jumlah ruang kuliah/sesi yang tersedia dengan ruang kuliah/sesi yang terpakai, merupakan sisa ruang kuliah/sesi yang dapat menampung calon mahasiswa baru semester ganjil 2017/2018. Dan jumlah inilah yang akan menjadi target jumlah mahasiswa baru yang dapat direkrut oleh tim promosi Universitas Bhayangkara Jaya.

Banyaknya ruang kuliah/sesi yang tersedia adalah: jumlah ruangan $\mathrm{x}$ frekuensi penggunaan ruangan dalam 1 hari x jumlah hari dalam satu minggu.

Banyaknya ruang kuliah/sesi yang dipakai : jumlah matakuliah/sesi

Sisa ruang kuliah/sesi adalah: banyaknya ruang kuliah/sesi yang tersedia - banyaknya ruang kuliah/sesi yang dipakai. Banyaknya mahasiswa yang dapat ditampung pada sisa ruang kuliah/sesi adalah sisa ruang kuliah/sesi x jumlah mahasiswa rata-rata per ruangan: 8 mata kuliah. 8 mata kuliah adalah rata-rata mahasiswa mengambil banyaknya matakuliah dalam satu semester.

\section{HASIL DAN PEMBAHASAN PENELITIAN}

Untuk menghitung banyaknya ruang kuliah yang tersedia, dirumuskan terlebih dahulu pengertian sebagai berikut:

1. Banyaknya ruangan $=$ jumlah ruang fisik yang ada.

2. Ruang kuliah = ruang yang dipakai untuk sesi perkuliahan

3. 1 (satu) sesi perkuliahan $=2$ (dua) sks atau 3 (tiga) sks

4. Untuk perkuliahan pada hari senin s.d jum'at 1 ruangan di UBJ digunakan 5 kali jam perkuliahan/sesi.

5. Untuk perkuliahan pada hari sabtu 1 ruangan di UBJ digunakan 3 kali jam perkuliahan/ sesi.

6. Sehingga banyaknya ruang kuliah/sesi yang tersedia pada hari senin s.d jum'at = banyaknya ruangan dikalikan 5 (lima), dan dikalikan 5 (lima). 
7. Sedangkan banyaknya ruang kuliah yang tersedia pada hari sabtu = banyaknya ruangan dikalikan 3 (tiga).

8. Banyaknya mata kuliah yang dilaksanakan, secara aktual dapat dihitung dari jadwalkuliah/ roster yang disusun oleh masing-masing fakultas.

9. Banyaknya ruang kuliah/sesi idealnya harus lebih besar dari banyaknya mata kuliah yang dilaksanakan.

10. Banyaknya mata kuliah dapat pula dihitung secara pendekatan dengan rumus $=$ banyaknya jumlah mahasiswa/fakultas x 8

35 mahasiswa

Dasar untuk menghitung ruang kuliah yang masih tersedia adalah sebagai berikut:

1. Data jumlah mahasiswa semester genap tahun akademik 2016/2017 per fakultas yang didapat datanya dari BAA (Biro Administrasi Akademik).

2. Jadwal kuliah/ Roster dari masing-masing fakultas.

3. Data ruangan yang dipergunakan pada masing-masing fakultas yang terdapat pada jadwal kuliah/ Roster dari masing-masing fakultas.

Hasil penelitian ini dapat di rangkum sebagai berikut:

Tabel 1: Hasil Hitungan banyaknya ruang Kuliah/sesi

\begin{tabular}{lccccc}
\hline \multicolumn{1}{c}{ Fakultas } & $\begin{array}{c}\text { Jumlah } \\
\text { Ruangan Fisik }\end{array}$ & $\begin{array}{c}\text { Jumlah } \\
\text { Mahasiswa }\end{array}$ & $\begin{array}{c}\text { Ruang kuliah } \\
\text { tersedia }\end{array}$ & $\begin{array}{c}\text { Jumlah } \\
\text { Mata Kuliah }\end{array}$ & $\begin{array}{c}\text { Sisa Ruang } \\
\text { Kuliah }\end{array}$ \\
\hline Ekonomi & 16 & 1605 & 448 & 342 & 106 \\
\hline Teknik & 23 & 2285 & 644 & 579 & 65 \\
\hline Komunikasi & 9 & 806 & 252 & 178 & 74 \\
\hline Psikologi & 9 & 652 & 252 & 141 & 111 \\
\hline Hukum & 8 & 904 & 224 & 205 & 19 \\
\hline Pasca & 8 & 191 & 224 & 46 & 178 \\
Sarjana & & & & & $\mathbf{1 4 9 1}$ \\
\hline \multicolumn{1}{c}{ Total } & $\mathbf{7 3}$ & $\mathbf{6 4 4 3}$ & $\mathbf{2 0 4 4}$ & \\
\hline
\end{tabular}

Untuk menghitung Ruang kuliah yang tersedia, sebagai contoh untuk Fakultas Ekonomi:

Banyaknya ruang kuliah/sesi (Senin s.d Jum'at) $=16 * 5 * 5=400$.

Banyaknya ruang kuliah/sesi (Sabtu) $\quad=16 * 3=48$._Total Ruang Kuliah/sesi yang tersedia $=400+48=448$. Banyaknya mata kuliah yang disajikan $=342$ mata kuliah. Adapun sisa ruang kuliah/sesi $=448-342=106$ ruang kuliah. Cara Hitungan yang sama dilakukan untuk Fakultas lainnya. 


\section{Keterangan Tabel-1 :}

a. Jumlah ruang kuliah/sesi yang tersedia adalah 2044 sesi.

b. Jumlah matakuliah yang dilaksanakan adalah 1491 .

c. Sisa ruang kuliah/sesi yang masih tersedia adalah sebanyak : 2044-1491 $=553$. Untuk pengecekan dapat digunakan rumus pendekatan banyaknya ruang kuliah yang tersedia dari hari senin s.d jum'at $=73 * 5 * 5=1825$.

d. Banyaknya ruang kuliah yang tersedia di hari sabtu $=73 * 3=219$.

e. Total ruang kuliah yang tersedia $=1825+219=2044$

f. Jumlah mata kuliah/ sesi (pendekatan $)=(6443: 35) * 8=1472.68$ pembulatan menjadi 1473.

g. $\quad$ Sisa ruang kuliah (pendekatan) $=2044-1473=571$.

h. Terdapat devisiasi sisa ruang kuliah/sesi $=571-553=18$ ruang kuliah/sesi, yang dalam persentase $=(18: 553) * 100 \%=3.25 \%$. Sehingga secara rumus pendekatan dapat diterima karena devisiasinya masih lebih kecil dari 5\%.

Seberapa banyak mahasiswa yang masih dapat di terima kuliah di UBJ dengan 553 ruang kuliah/sesi?. Jika diasumsikan untuk 1 mata kuliah diikuti oleh sebanyak 35 orang, dan 1 mahasiswa mengambil 8 mata kuliah (dalam hal ini yang diambil adalah jumlah matakuliah yang terbanyak dapat diambil dalam satu semester oleh satu mahasiswa), maka banyaknya mahasiswa yang dapat diterima di UBJ $=(553: 8) * 35=2419.4$ dengan pembulatan 2419 orang. Dengan demikian, maka sebagai target penerimaan mahasiswa baru untuk tahun ajar 2017/2018 adalah sebanyak 2419 orang.

Tentunya untuk dapat menerima mahasiswa baru sejumlah 2419 orang, maka sebagai implikasi manajerialnya adalah:

1. Pengaturan ruang (fisik) kuliah dilakukan oleh pihak Universitas, bukan oleh fakultas/ prodi.

2. Dalam menyusun jadwal perkuliahan, diusahakan semua ruangan, penggunaan dalam satu hari harus dioptimalkan terlebih dahulu, baru kemudian mengisi untuk hari berikutnya. Dengan catatan, diusahakan tidak ada 2 atau 3 matakuliah yang waktunya sama untuk semester yang sama (di ganjil atau di genap).

3. Dalam menyusun jadwal perkuliahan/ roster, dosen tetap harus mengikuti jadwal yang telah ditetapkan oleh fakultas/ prodi. Dalam hal ini dosen tetap sedapat mungkin tidak boleh memilih hari dan jam perkuliahan. Atau setiap dosen tetap harus mengikuti point 2 .

4. Dalam menyusun jadwal perkuliahan bagi dosen tidak tetap, sedapat mungkin harus mengikuti jadwal dan waktu yang tersedia (dalam arti sedapat mungkin tidak memilih hari dan jam perkuliahan), sehingga pemakaian ruangan menjadi optimum. (atau mengikuti point 2)

5. Dilakukan pengaturan seperti tersebut dalam point $1 \mathrm{~s} / \mathrm{d} 4$, , agar tidak terjadi penumpukkan dosen di suatu hari (misalnya di hari Sabtu), sedangkan di hari lainnya terdapat ruang kuliah atau pemakaian ruangan yang idle.

6. Pengaturan dari point $1 \mathrm{~s} / \mathrm{d} 4$ yang paling baik adalah menggunakan pemrograman komputer/ menggunakan sistem IT.

Dengan pengaturan tersebut, maka frekuensi penggunaan ruangan menjadi optimal, okupansi ruangan menjadi optimal dan Space utilisasion menjadi tinggi. 


\section{KESIMPULAN}

Dari hasil penelitian ini dapat disimpulkan sebagai berikut:

1. Dengan student body 6443 dan banyaknya ruangan 73 ruangan, maka ruang kelas/sesi yang masih tersedia adalah sebanyak 553 ruang kelas/ 553 sesi kuliah. Berarti pemakaian ruang kuliah belum optimum.

2. Jumlah mahasiswa yang dapat ditampung pada 553 ruang kuliah adalah sebanyak 2419 mahasiswa

3. Dengan demikian target tim promosi Universitas Bhayangkara adalah menerima calon mahasiswa sebanyak 2419 orang untuk tahun ajar 2017/2018.

\section{REFERENSI}

Hesti Maheswari.(2010).Optimasi Kapasitas Dalam Meningkatkan Efisiensi dan Pengembalian Investasi (Studi Kasus pada Universitas Mercu Buanan Jakarta). Pamator, Volume 3, nomor 2 , Oktober 2010.

Heizer J \& Render Barry. (2008) Operation Management, 6th edition, Prentice-Hall International Inc., New Jersey.

Martinich, Joseph S. (1997) Production and Operation Management An Applied Modem Approach, John Willey \& Suns Inc., New York.

Panday, Rorim (2015). Evaluasi Penggunaan Ruangan Bangunan Untuk Mengoptimalkan Utilisasinya Pada Pemakaian Gedung Fakultas Teknik Universitas Pakuan. Makalah dalam Proceeding Seminar Nasional dan Call For Paper Universitas Kristen Maranatha, Bandung.

Standar Nasional Pendidikan.(2005). Peraturan Pemerintah Nomor 19 tahun 2005 tentang Standar Nasional Pendidikan.

UK Higher Education. (2006). Space Management Project, Space utilisation: practice, performance and guidelines. 